\title{
DEVELOPMENT OF ELECTROCHROMIC DEVICES WORKING WITH HYDROPHOBIC LITHIUM ELECTROLYTE
}

\author{
NAM-GYU PARK ${ }^{\mathrm{a}}$, ARMEL POQUET ${ }^{\mathrm{a}}$, GUY CAMPET ${ }^{\mathrm{a}, *}$, \\ JOSIK PORTIER ${ }^{\mathrm{a}}$, JIN-HO CHOY ${ }^{\mathrm{b}}$, YOUNG-IL KIM ${ }^{\mathrm{b}}$, \\ D. CAMINO ${ }^{c}$ and J. SALARDENNE ${ }^{c}$ \\ ${ }^{a}$ Institut de Chimie de la Matière Condensée de Bordeaux \\ (ICMCB)-CNRS, Université de Bordeaux I, Château Brivazac, \\ Av. du Dr. A. Schweitzer, 33608 Pessac, France; ' Department of Chemistry, \\ Center for Molecular Catalysis, College of Natural Sciences, \\ Seoul National University, Seoul 151-742, Korea; ${ }^{\mathrm{C}}$ Centre de Physique \\ Moléculaire Optique et Herziennne (CPMOH), Université de Bordeaux I, \\ 351 cours de la Libération, 33405 Talence, France
}

(Received 27 February 1997; In final form 13 March 1997)

\begin{abstract}
This manuscript report on a new lithium electrolyte, allowing the manufacturing of electrochemical systems, such as electrochromic devices, in ambient atmosphere. It is based on lithium bis-trifluoromethane sulfonimide dissolved in the following hydrophobic salt, which was first prepared by M. Grätzel et al.: 1-ethyl. 3-methyllimidazolium bis-trifluoromethane sulfonimide. We have also successfully tested the compatibility of this electrolyte with $\mathrm{WO}_{3}$ and $\mathrm{TiO}_{2}-\mathrm{CeO}_{2}$ films acting respectively as efficient electrochromic electrode and counter electrode for smart-window working with $\mathrm{Li}^{+}$ions.
\end{abstract}

Keywords: Electrochromism; hydrophobic electrolyte

\section{INTRODUCTION}

Thin film electrochromic (EC) materials (ECM) and electrochromic devices (ECD) present a basis for light modulators and other electrooptic devices [1-11]. The ECD can be presumed as a system,

*Corresponding author. 
containing an electrochromic material $\left(\mathrm{ECM}_{1}\right)$, a lithium ion conducting electrolyte $\left(\mathrm{Li}^{+}-\mathrm{IC}\right)$, and a counter electrode $\left(\mathrm{EMC}_{2}\right)$. This assembly is sandwiched between two identical transparent electronic conductors (ITO $\equiv$ Indium tin oxide) serving as ohmic contacts. $\mathrm{EMC}_{1}$ switches from the transparent to the colored state during the cathodic process when electrons and $\mathrm{Li}^{+}$ions are injected into it. These electrons and cations which are provided by $\mathrm{ECM}_{2}$, transit via the external circuit and the electrolyte respectively. The process must be reversible. $\mathrm{ECM}_{2}$ can either optically switch in a complementary way of $\mathrm{ECM}_{2}$ or can remain transparent in both the inserted and deinserted states.

The most important problem to solve is the fabrication of efficient $\mathrm{Li}^{+}$-IC, $\mathrm{EMC}_{1}$ and $\mathrm{ECM}_{2}$ components, which allow the manufacturing process of ECD in open air, i.e., outside the inert atmosphere of the drybox. The use of the dry-box is indeed unrealistic for obvious practical reasons; it means, for instance, that hydrophobic $\mathrm{Li}^{+}-\mathrm{IC}$ have to be used. This paper report on $\mathrm{Li}^{+}-\mathrm{IC}, \mathrm{ECM}_{1}$ and $\mathrm{ECM}_{2}$ components allowing this important aim to be attained.

(i) $\mathrm{Li}^{+}-\mathrm{IC}$ is a hydrophobic electrolyte of high ionic conductivity.

Recently, new hydrophobic ionic liquids with low melting temperature, low vapor pressure and high conductivity have been investigated: they are based on hydrophobic ions. Among these hydrophobic ionic liquids we have focused on the following ionic liquids which was first prepared by M. Gräetzel et al. [12]:

\section{1, 3-EtMeIm ${ }^{+} \quad\left(\mathrm{CF}_{3} \mathrm{SO}_{2}\right)_{2} \mathrm{~N}^{-}$ \\ cation counter anion \\ hydrophobic liquid salt}

We have indeed successfully used this hydrophobic liquid salt as a solvent for the solid salt: $\mathrm{Li}\left(\mathrm{CF}_{3} \mathrm{SO}_{2}\right)_{2} \mathrm{~N}$. That allows us to obtain a new hydrophobic lithium electrolyte of high conductivity, recently patented by some of us [13].

(ii) $\mathrm{ECM}_{1}$ is a $\mathrm{WO}_{3}$ film coated, using the sputtering technique, on ITO glass (ITO glass $\equiv$ transparent and conducting Indium Tin Oxide deposited in a glass substrate). 
Various kinds of inorganic or organic $\mathrm{ECM}_{1}$ have been proposed and their electrochromic properties have been extensively studied [1-11]. Among them, tungsten oxide is one of the most promising materials for electrochromic devices because of its advantages of a good perceived contrast, memory effect and low switching voltage, when it is in a porous nanocrystalline form.

$$
\begin{array}{lc}
\mathrm{WO}_{3}+x \mathrm{Li}^{+}+x \mathrm{e}^{-} \longleftrightarrow \mathrm{Li}_{x} \mathrm{WO}_{3} \\
\text { colorless } & \text { blue } \\
\text { low conductivity } & \text { high conductivity }
\end{array}
$$

Several techniques have been used to prepare these porous tungsten oxide films, such as sputtering, evaporation, electrodeposition, chemical vapor deposition, spray pyrolysis and sol-gel methods [1-11]. We have selected, here the sputtering technique which allow us to produce large size films $\left(30 \times 30 \mathrm{~cm}^{2}\right)$ meeting, therefore, the industrial needs.

(iii) $\mathrm{ECM}_{2}$ is a $\mathrm{TiO}_{2}-\mathrm{CeO}_{2}$ film deposited on ITO glass using RF sputtering.

Some of us have established that cerium doped titanium oxide $\left(\mathrm{TiO}_{2}-\mathrm{CeO}_{2}\right)$ is an efficient transparent counter electrode [14-15]: it has been shown that $\mathrm{Ce}^{4+}$ acts, indeed, as a deep acceptor center for the electrons. It implies that the $\mathrm{Ce}^{4+} \leftrightarrow \mathrm{Ce}^{3+}$ reduction-oxidation will take place during the $\mathrm{Li}^{+}$insertion-deinsertion process and will, therefore, inhibit the $\mathrm{Ti}^{4+}$ reduction, thereby maintaining the film transparency.

\section{EXPERIMENTAL}

\section{Component Preparation}

(i) The Hydrophobic $\mathrm{Li}^{+}-\mathrm{IC}$

As quoted above, it is based on lithium bis-trifluoromethanesulfonimide dissolved in hydrophobic 1-ethyl-3-methyllimidazolium bis-trifluoromethane sulfonimide [12]. 
The schematic synthesis route is depicted below:

$$
\begin{aligned}
& \text { 1-MeIm } \stackrel{\mathrm{CH}_{2} \mathrm{BrCH}_{3}}{\longrightarrow} \underset{\mathrm{EtMelm}^{+} \mathrm{Br}^{-}}{\stackrel{\mathrm{Li}^{+}\left(\mathrm{CF}_{3} \mathrm{SO}_{2}\right)_{2} \mathrm{~N}^{-}}{\longrightarrow}} \\
& 1,3-\mathrm{EtMeIm}^{+}\left(\mathrm{CF}_{3} \mathrm{SO}_{2}\right)_{2} \mathrm{~N}^{-} \\
& \text {1, 3-EtMeIm }{ }^{+}\left(\mathrm{CF}_{3} \mathrm{SO}_{2}\right)_{2} \mathrm{~N}^{-} \frac{\mathrm{Li}^{+}\left(\mathrm{CF}_{3} \mathrm{SO}_{2}\right)_{2} \mathrm{~N}^{-}}{10 \% \text { by weight }} \\
& \text { hydrophobic } \mathrm{Li}^{+} \text {-IC (gel type) }
\end{aligned}
$$

In order to synthesize the hydrophobic $\mathrm{Li}^{+}-\mathrm{IC}$, we first mixed $136 \mathrm{~cm}^{3}$ of $1,1,1$ trichloroethane (Prolabo 94\%) with $24,3 \mathrm{~cm}^{3}$ of 1-methylimidazole (Aldrich 99\%) under vigorous stirring. $100 \mathrm{~g}$ of bromoethane (Aldrich 99+\%) were then dropped out, into the solution, for 1 hour. Afterwards, the solution was refluxed for $2 \mathrm{hrs}$ at around $80^{\circ} \mathrm{C}$, allowing the reaction to proceed. The so-obtained liquid molten salt was immediately washed 3 times with $100 \mathrm{~cm}^{3}$ of 1, 1, 1 trichloroethane. Finally, $19 \mathrm{~g}$ of the crystallized product. 1,3EtMeIm ${ }^{+} \mathrm{Br}^{-}$(whose melting point is $76^{\circ} \mathrm{C}$ ) was obtained. After drying under primary vacuum for 1 hour, it was dissolved in $45.5 \mathrm{~cm}^{3}$ of distilled water. We separately dissolved $28 \mathrm{~g}$ of $\mathrm{Li}\left(\mathrm{CF}_{3}\right.$ $\left.\mathrm{SO}_{2}\right)_{2} \mathrm{~N}$ in $90 \mathrm{~cm}^{3}$ of distilled water. The two solutions were intimately mixed under vigorous stirring, at $70^{\circ} \mathrm{C}$ for 30 mins. Finally the 2 phases were separated and, after heating at $70^{\circ} \mathrm{C}$ under primary vacuum for 1 hour, the hydrophobic salt 1,3-EtMeIm $\left(\mathrm{CF}_{3} \mathrm{SO}_{2}\right)_{2} \mathrm{~N}$, was obtained $(35 \mathrm{~g})$. In order to get the expected hydrophobic $\mathrm{Li}^{+}-\mathrm{IC}$, we dissolved $3.5 \mathrm{~g}$ of $\mathrm{Li}\left(\mathrm{CF}_{3} \mathrm{SO}_{2}\right)_{2} \mathrm{~N}$ into the $35 \mathrm{~g}$ of the hydrophobic salt.

\section{(ii) The Electrochromic Material ECM $: \mathrm{WO}_{3}$}

The $\mathrm{WO}_{3}$ films were either provided by Dr. A. Richardt, President of the Society Inland Europe-Paris (France), or deposited in our laboratory using planar magnetron Balzer BAS 450 PM apparatus. We have optimized the sputtering experimental conditions which are listed in Table I. 
TABLE I Sputtering Experimental Condition for $\mathrm{WO}_{3}$ film

\begin{tabular}{lcccc}
\hline Target & Atmosphere & Power & $\begin{array}{c}\text { Target to substrate } \\
\text { distance }\end{array}$ & $\begin{array}{c}\text { Substrate } \\
\text { Temperature }\end{array}$ \\
\hline $\mathrm{W}$ & $\mathrm{O}_{2}(50 \%)+\mathrm{Ar}(50 \%)$ & $1000 \mathrm{~W}$ & $10 \mathrm{~cm}$ & $70^{\circ} \mathrm{C}$ \\
$(\varnothing=30 \mathrm{~cm})$ & $10^{-2} \mathrm{mbar}$ & & & $150^{\circ} \mathrm{C}$ \\
\hline
\end{tabular}

\section{(iii) The Counter Electrode Material $\mathrm{ECM}_{2}: \mathrm{TiO}_{2}-\mathrm{CeO}_{2}$}

The sputtering conditions for various compositions are listed in Table II.

\section{Film Characterizations}

$\mathrm{X}$-ray diffraction measurements were carried out, using $\mathrm{CuK} \alpha$ radiation, to investigate the film structure. A JEOLJSM-840 A apparatus, allowing scanning or transmission electron microscopy (SEM or TEM) was used to determine the film texture, thickness and composition.

\section{Electrochemical and Spectro Photometric Measurements}

Electrochemical experiments were performed with a computercontrolled potentiostat/galvanostat (TACUSSEL, PGS $201 T$ model)

TABLE II RF-Sputtering Conditions for $\left(\mathrm{TiO}_{2}\right)-\left(\mathrm{CeO}_{2}\right)$

\begin{tabular}{lcccc}
\hline Target & Atmosphere & Power & $\begin{array}{c}\text { Target to substrate } \\
\text { distance }\end{array}$ & $\begin{array}{c}\text { Substrate } \\
\text { temperature }\end{array}$ \\
\hline $\left.\mathrm{TiO}_{2}\right)$ & $\begin{array}{c}\mathrm{O}_{2} \text { and } \mathrm{O}_{2} / \mathrm{N}_{2}=1 \\
5 \times 10^{-2} \mathrm{mbar}\end{array}$ & $60 \mathrm{~W}$ & $10 \mathrm{~cm}$ & $50^{\circ} \mathrm{C}$ \\
$\left(\mathrm{TiO}_{2}\right)_{0.9}-$ & $\mathrm{O}_{2}$ and $\mathrm{O}_{2} / \mathrm{N}_{2}=1$ & & & \\
$\left(\mathrm{CeO}_{2}\right)_{0.1}$ & $5 \times 10^{-2} \mathrm{mbar}$ & $50 \mathrm{~W}$ & $10 \mathrm{~cm}$ & $50^{\circ} \mathrm{C}$ \\
$\left(\mathrm{TiO}_{2}\right)_{0.66}^{-}$ & $\mathrm{O}_{2}$ and $\mathrm{O}_{2} / \mathrm{N}_{2}=1$ & & & \\
$\left(\mathrm{CeO}_{2}\right)_{0.33}$ & $5 \times 10^{-2} \mathrm{mbar}$ & $47.5 \mathrm{~W}$ & $10 \mathrm{~cm}$ & $50^{\circ} \mathrm{C}$ \\
$\left(\mathrm{TiO}_{2}\right)_{0.5}^{-}$ & $\mathrm{O}_{2}$ and $\mathrm{O}_{2} / \mathrm{N}_{2}=1$ & & & \\
$\left(\mathrm{CeO}_{2}\right)_{0.5}$ & $5 \times 10^{-2} \mathrm{mbar}$ & $47.5 \mathrm{~W}$ & $10 \mathrm{~cm}$ & $50^{\circ} \mathrm{C}$ \\
$\left(\mathrm{TiO}_{2}\right)_{0.2}^{-}$ & $\mathrm{O}_{2}$ and $\mathrm{O}_{2} / \mathrm{N}_{2}=1$ & & & \\
$\left(\mathrm{CeO}_{2}\right)_{0.8}$ & $5 \times 10^{-2} \mathrm{mbar}$ & $42.5 \mathrm{~W}$ & $10 \mathrm{~cm}$ & $50^{\circ} \mathrm{C}$ \\
& $\mathrm{O}_{2}$ and $\mathrm{O}_{2} / \mathrm{N}_{2}=1$ & & & \\
$\left(\mathrm{CeO}_{2}\right)$ & $5 \times 10^{-2} \mathrm{mbar}$ & $40 \mathrm{~W}$ & $10 \mathrm{~cm}$ & $50^{\circ} \mathrm{C}$ \\
\hline
\end{tabular}


for the electrochemical cell of Pt/LiTFSI + 1,3-EtMelmTFSI/ $\mathrm{WO}_{3}$ (or $\mathrm{TiO}_{2}-\mathrm{CeO}_{2}$ ). All the measurements were advantageously performed at room temperature in air owing to the hydrophobic character for the lithium electrolyte (The $\mathrm{Pt}$ voltage was standardized versus a $\mathrm{Li}$ electrode). The electrochemical lithium insertion/deinsertion was processed under various charge densities which were repeated automatically. Optical properties of the colored and bleached states were investigated using a UV-Vis-NIR spectrophotometer (Varian Cary 2415 Spectrophotometer equipped with DS-15 Data Station). The ionic conductivity of the electrolyte was determined from impedance measurements using a Solartron impedancemeter.

\section{RESULTS}

Most interestingly, the hydrophobic $\mathrm{Li}^{+}-\mathrm{IC}$, -whose water content is less than 3\% (Karl Fisher analysis)-, is electrochemically stable over a large electrochemical window (Fig. 1). Moreover, its room tempera-

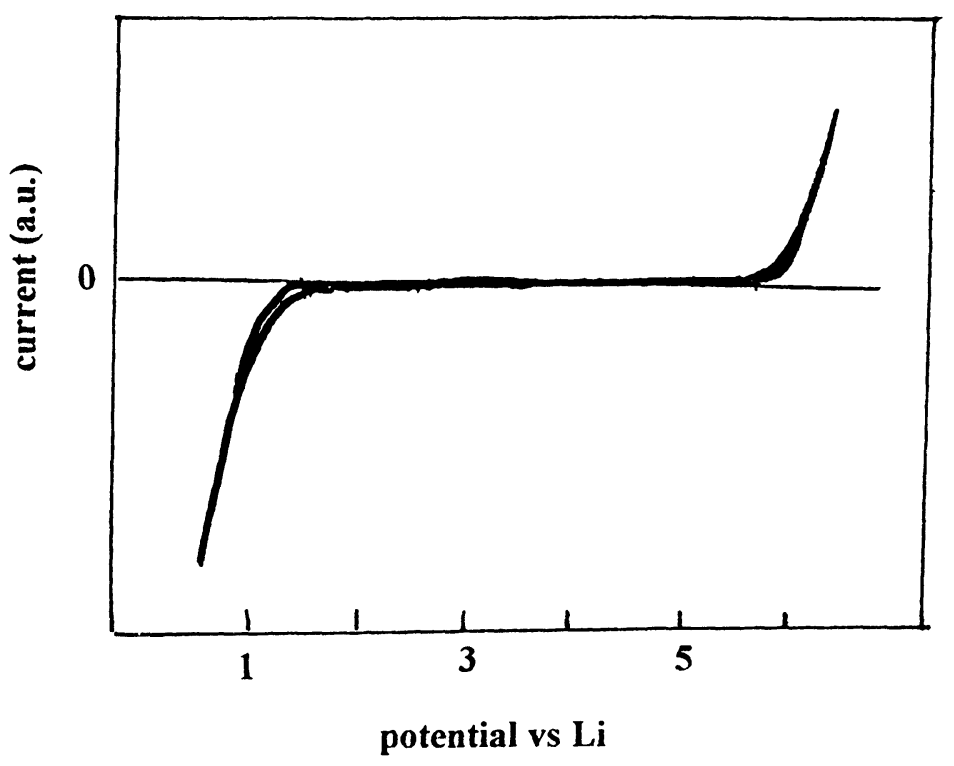

FIGURE 1 Cyclic voltammograms of the hydrophobic $\mathrm{Li}^{+}-\mathrm{IC}$ (anode=lithium metal; cathode $=$ stainless steel). 
ture conductivity, which is deduced form impedance measurements using a Solartron impedancemeter-, is larger than $10^{-3} \Omega^{-1} \mathrm{~cm}^{-1}$ (Fig. 2).

The Figure 3 shows the TEM photographs of the $\mathrm{WO}_{3}$ films prepared at $70^{\circ} \mathrm{C}(\mathrm{A})$ and $150^{\circ} \mathrm{C}(\mathrm{B})$. The photo A evidences crystallites of about $10 \mathrm{~nm}$ diameter in a rather porous texture. A more dense film is observed on the photo $B$, and the crystallites have an average diameter of $30 \mathrm{~nm}$.

When the substrate temperature is higher than $150^{\circ} \mathrm{C}, 300^{\circ} \mathrm{C}$ for instance, the films are highly dense with an average crystallite size of $100 \mathrm{~nm}$. We are then dealing with the orthorhombic variety of $\mathrm{WO}_{3}$. The color changes are less marked in these film due to the too high crystallinity. That is the reason why we have finally used the two substrate temperatures which are quoted in the table $\left(70^{\circ} \mathrm{C}\right.$ and $\left.150^{\circ} \mathrm{C}\right)$.

The Figure 4 represents the evolution of the inserted charge $\left(\mathrm{Li}^{+}\right)$as a function of the film thickness for the two types of films. A formating process, accounting for the inserted charge difference between the first

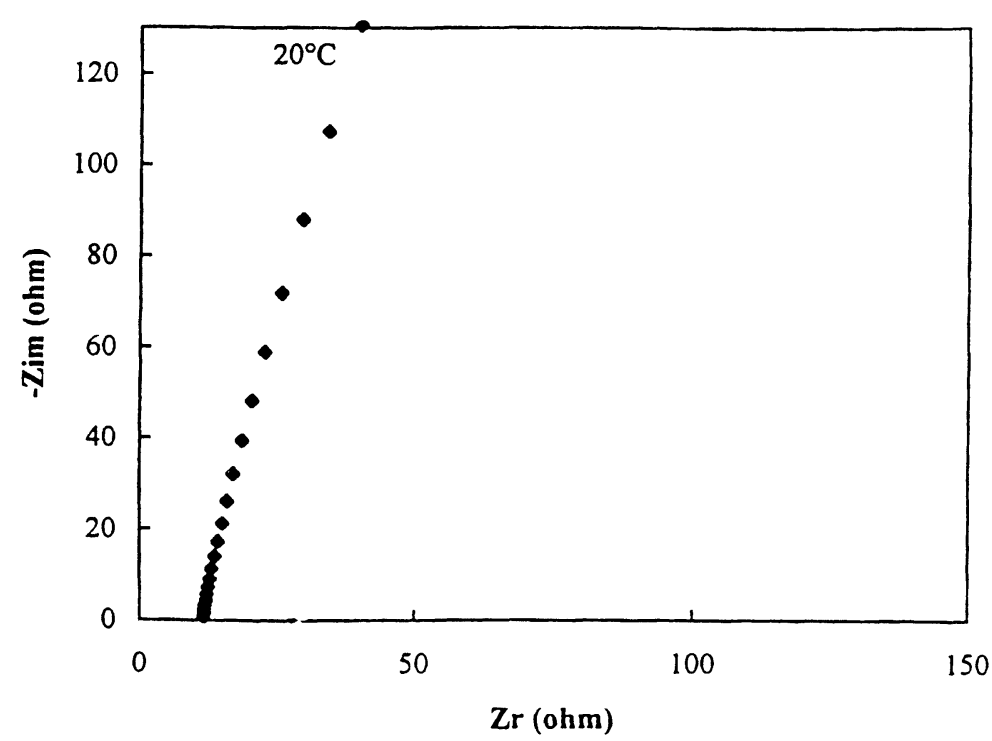

FIGURE 2 Impedance data (from $1 \mathrm{~Hz}$ to $1 \mathrm{MHz}$ ) of the hydrophobic $\mathrm{Li}^{+}$-IC (the electrolyte is sandwiched between two stainless steel electrodes). 


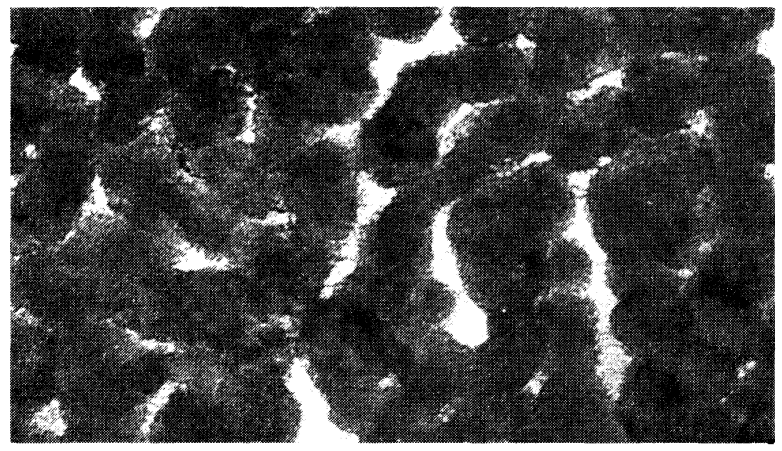

A

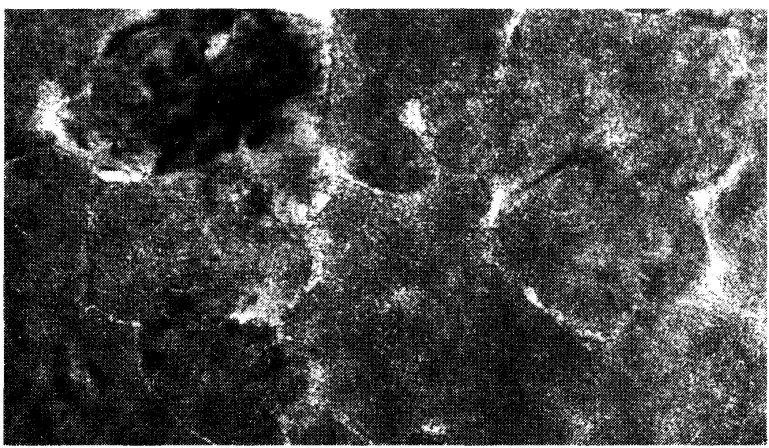

B

$1 \mathrm{~cm}=10 \mathrm{~nm}$

FIGURE 3 TEM photographs of the films prepared at $70^{\circ} \mathrm{C}$ (A) and $150^{\circ} \mathrm{C} \mathrm{(B)}$.

insertion step (i) and the following insertion-deinsertion steps (ii), is more pronounced for the more porous films, A. This formating process corresponds, very likely, to the reduction of the adsorbed oxygen such as $\mathrm{O}_{2}^{2-}$ in the nanoscale structure (surface contamination):

$$
\mathrm{WO}_{3}+2 \mathrm{Li}^{+}+0.5 \mathrm{O}_{2}^{2-}+2 \mathrm{e}^{-} \longrightarrow \mathrm{WO}_{3}+\mathrm{Li}_{2} \mathrm{O}
$$

The Figure 5 gives the evolution of the change in optical density $(\triangle O D)$, defined here as $\ln \left(T_{\text {bleach }} / T_{\text {color }}\right)$, as a function of the reversible inserted charge $\left(\mathrm{Li}^{+}\right)$, for the films $\mathrm{A}$ and $\mathrm{B}$. We see that 

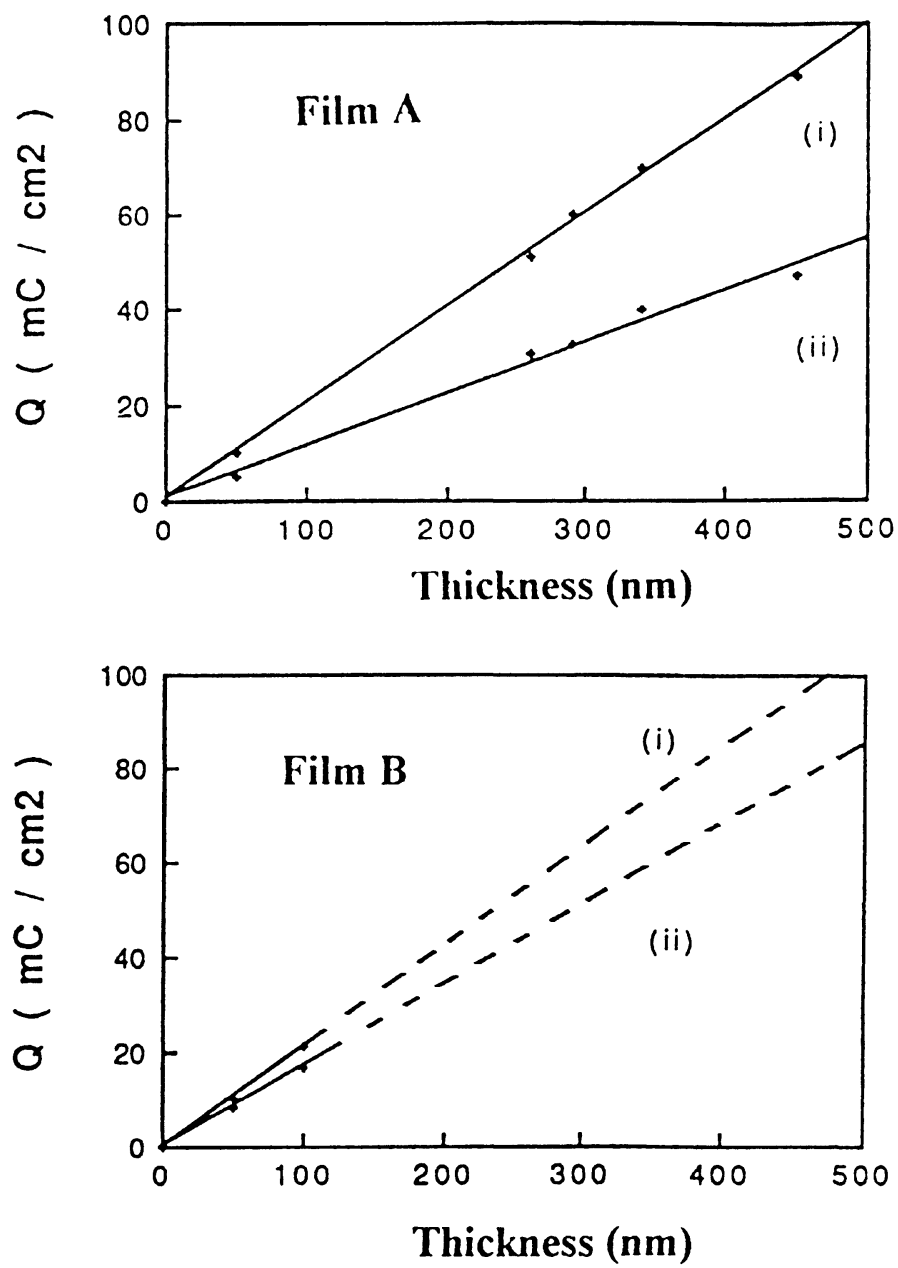

FIGURE 4 Evolution of $Q$, which is the inserted charge $\left(\mathrm{Li}^{+}\right)-$, as a function of the film thickness $\left(\mathrm{WO}_{3}\right.$ films $\mathrm{A}$ and $\mathrm{B} ; \mathrm{V}=2 \mathrm{~V}$ vs. $\mathrm{Li}$, (i) first insertion, (ii) following insertions and deinsertions).

$\triangle O D$ and therefore the optical coulombic efficiency $\Delta O D / \Delta Q$, i.e., coloration efficiency, is higher for the film A. Consequently, we believe that the film $A$ is the most interesting one (for an application point of view) in spite of the above mentioned formatting process. Moreover, the cyclic voltammogram of the film A, reported on the Figure 6, 

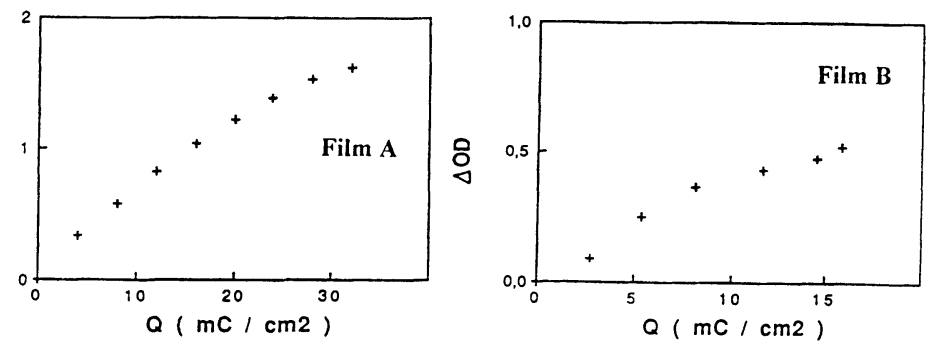

FIGURE 5 Evolution of the optical density, $\triangle O D$, as a function of $Q$, which is the reversible inserted charge $\left(\mathrm{WO}_{3}\right.$ films $\mathrm{A}$ and $\mathrm{B}$; film thickness $=3000 \AA$; $\lambda=550$ $\mathrm{nm})$.

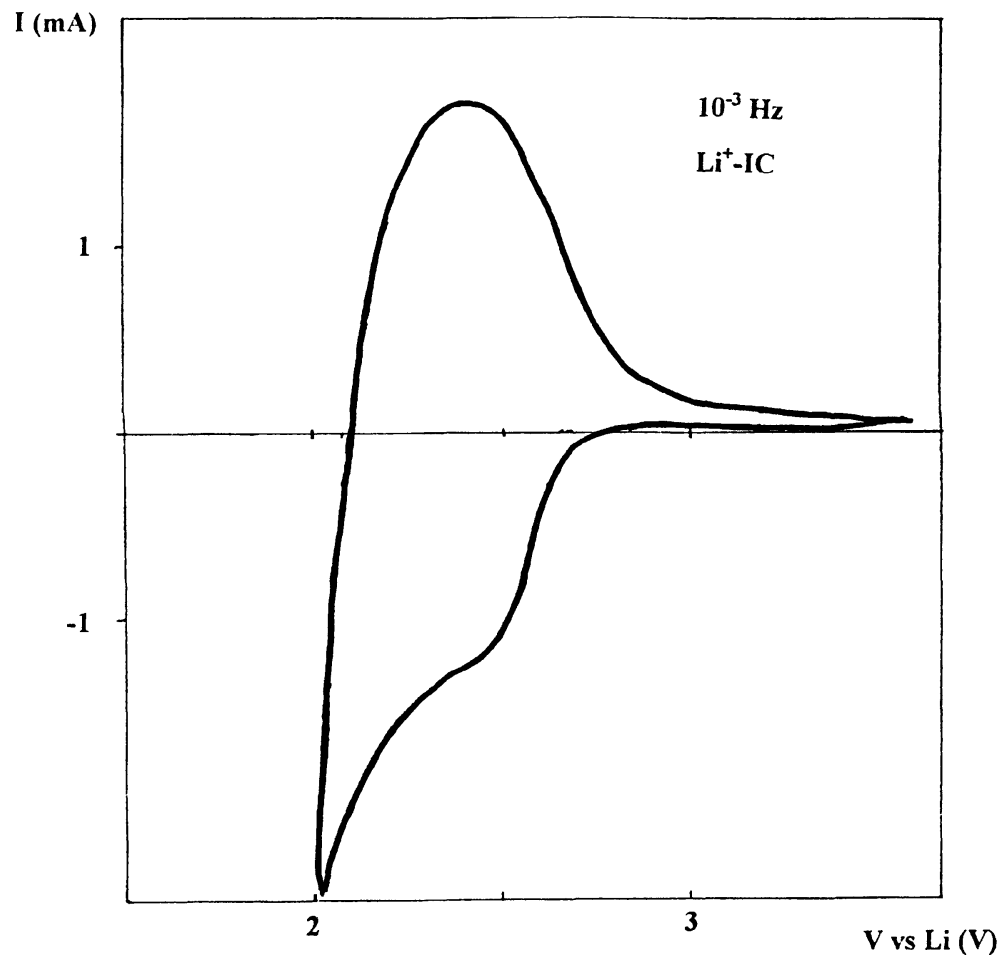

FIGURE 6 Cyclic voltammograms, in $\mathrm{Li}^{+}-\mathrm{IC}$, of $\mathrm{WO}_{3}$ : film A (anode=lithium metal; cathode $=$ glass $+\mathrm{ITO}+\mathrm{WO}_{3}$ ). 
shows that the insertion potential is larger than $2 V$ : it is, hopefully, within the stability domain of the hydrophobic Li-IC (Fig. 1).

Concerning the $\mathrm{TiO}_{2}-\mathrm{CeO}_{2}$ films, the achievement of a good transparency in both inserted and deinserted states is illustrated on the Figure 7 for the composition $\left(\mathrm{TiO}_{2}\right)_{0.9}\left(\mathrm{CeO}_{2}\right)_{0.1}$ : indeed, the absorption coefficient does not change in the whole visible range upon $\mathrm{Li}^{+}$insertion. The reversible $\mathrm{Ce}^{4+}+\mathrm{e} \leftrightarrow \mathrm{Ce}^{3+}$ redox process occuring during the $\mathrm{Li}^{+}$insertion process is evidenced on the Figure 8. showing the voltammogram for the composition $\left(\mathrm{TiO}_{2}\right)_{0.9}\left(\mathrm{CeO}_{2}\right)_{0.1}$; as shown in this figure, the electrode potential must remain larger than $\sim 2 V$ vs. $\mathrm{Li}$, in order to avoid the $\mathrm{Ti}^{4+}$ reduction and thereby maintain the film transparency.

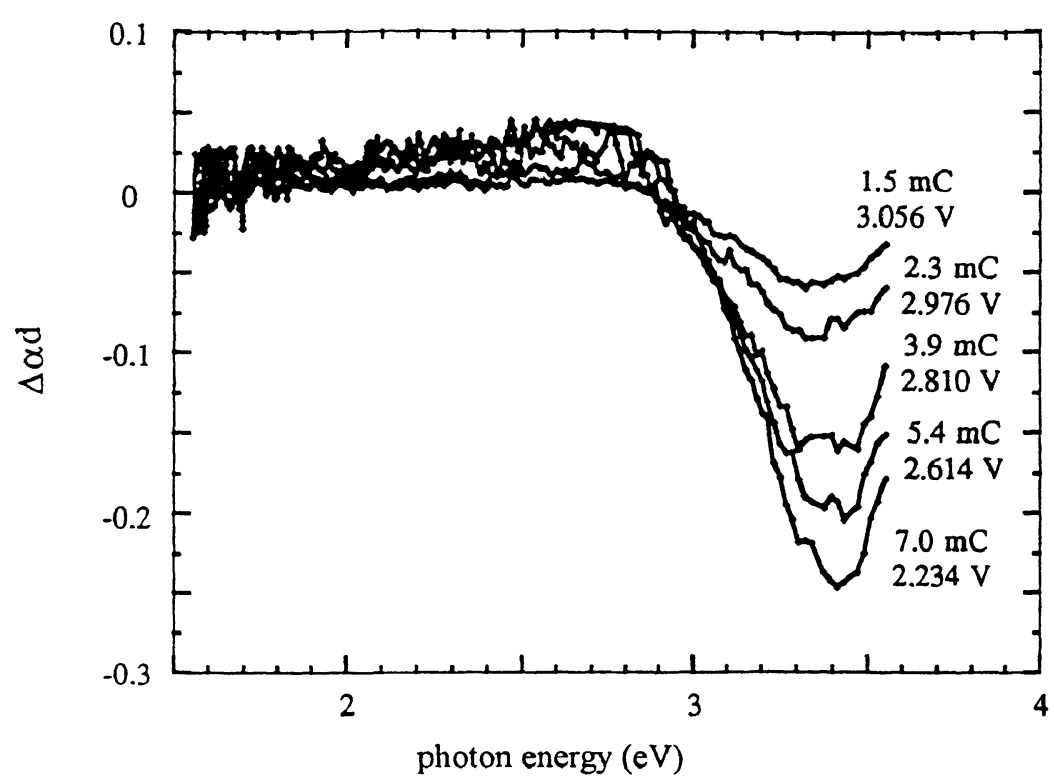

FIGURE 7 Variation of the absorption coefficient as a function of the inserted charge of a $\left(\mathrm{TiO}_{2}\right)_{0.9}\left(\mathrm{CeO}_{2}\right)_{0.1}$ film (film thickness $\left.=3000 \AA S=1 \mathrm{~cm}^{2}\right)$, deposited on glass + ITO). 


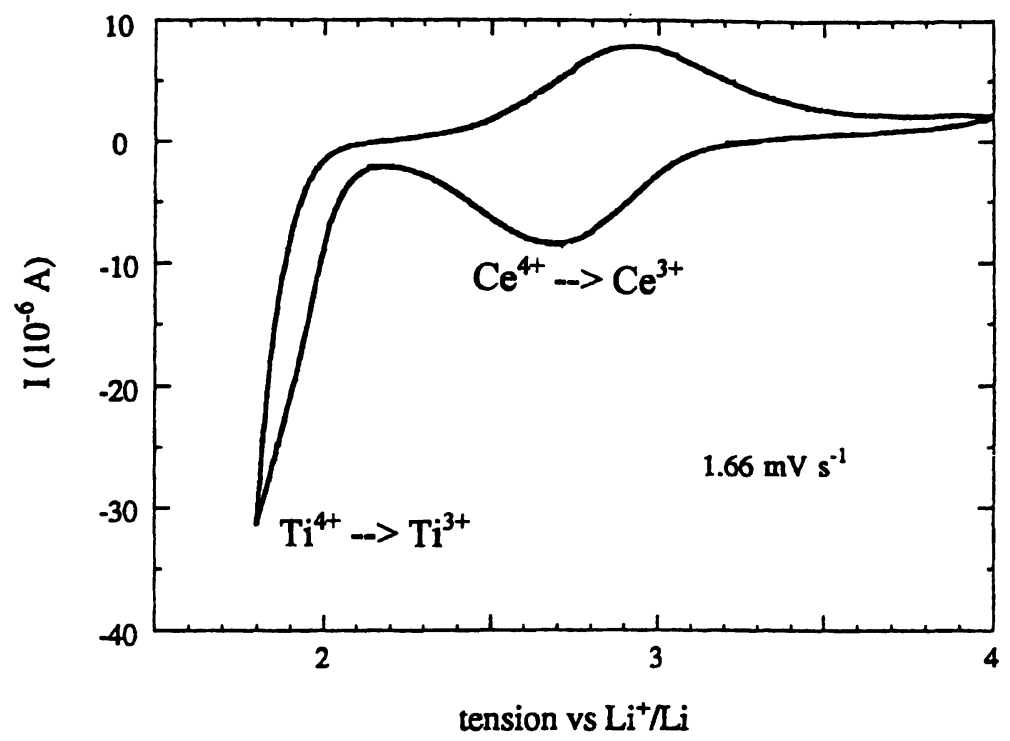

FIGURE 8 Voltammogram for the composition $\left(\mathrm{TiO}_{2}\right)_{0.9}\left(\mathrm{CeO}_{2}\right)_{0.1}$.

\section{CONCLUSIONS}

All the above mentioned results allow us to manufacture cheap and new electrochromic displays, ECD, which are based on the components presented in this manuscript. Let us quote that the ECD use $\mathrm{Li}^{+}$ions and not $\mathrm{H}^{+}$ones, so that they will have an efficient memory effect (over several days). The are easily manufactured in "open-air", and not in inert and costly atmosphere of a dry box as it generally occurs for other $\operatorname{ECD}\left(\mathrm{Li}^{+}\right)$, those which are very sensitive to water contamination due to the hydrophilic character of the ionic conducting electrolyte, $\mathrm{Li}^{+}$-IC. We have solved this problem by manufacturing new hydrophobic $\mathrm{LI}^{+}$-IC having also a high ionic conductivity and a low vapor pressure.

\section{Acknowledgement}

The authors wish to thank Dr. Aimé Richardt, President of the Society INLAND EUROPE (Paris, France) for providing us with large-size sputtered films. This work was supported in part by the KOSEF 
through the Center for Molecular Catalysis of the Seoul National University and by the Korean Ministry of Trade and Industry under a program of International Collaboration.

\section{References}

[1] Lampert, C. M. and Granqvist, C. G. (1990). "Large-Area Chromogenics: Materials and Devices for Transmittance Control", (Lampert, C. M. and Granqvist, C. G. Editors; Roy Potter, F. General Editor), 4, SPIE Optical Engineering Press., Bellingham, Washington.

[2] Campet, G., Portier, J., Morel, B., Bourrel, M. and Chabagno, J. M. (1992). "Electrochromism and Electrochromic Windows", Active and Passive Electronic Components, 14, 225.

[3] Czanderna, A. W., Benson, D. K., Zhang, J.-Z., Tracy, C. E. and Deb, S. K. "Overview of Criteria for Assessing The Durability of Electrochromic Windows for Buildings Applications", 2nd International Meeting on Electrochromism, IME2, San Diego, CA, U.S.A. (October 1996).

[4] Monk, P. M. S., Mortimer, R. J. and Rosseinsky, D. R. (1994). "Electrochromism: Fundamentals and Applications", (Gregory, P. and Anton, U. Editors) VCH. Weinheim, (references are therin).

[5] Granqvist, C. G. (1995). "Handbook of Inorganic Electrochromic Materials", Elsevier Science, B. V., Amsterdam, (references are therin).

[6] Van Rottkay, K., Rubin, M. and Wen, S.-J. "Optical Indices of Electrochromic Tungsten Oxide", Int. Conference on Metallurgical Coatings and Thin Films, San Diego, U.S.A. (April 1996).

[7] Rubi, M., Von Rottkay, K., Wen, S.-J., Lozer, N. and Slack, J. “Optical Indices of Electrochromic Oxides", SPIE's International Symposium on Optical Materials Technology for Energy Efficiency and Solar Energy Conversion XV, Freiburg, Germany (September 1996) (references are therin).

[8] Rubin, M., Wen, S.-J., Richardson, T., Keer, J., von Rottkay, K. and Slack, J. "Electrochromic Lithium Nickel Oxide by Pulsed Laser Deposition and Sputtering", same ref. as. 9.

[9] Giron, J. C. (1994). "Couches Minces d'Hydroxide de Nickel et d'Oxydes Mixtes Nickel/Lithium et Nickel/Sodium. Application aux systèmes électrochromes", $\mathrm{Ph}$. D. thesis, Université de Paris IV, France.

[10] Campet, G., Wen, S. J., Han, S. D., Sharstry, M. C. R. and Portier, J. (1993). "Reversible Electrochemical insertion of lithium in fine-grained polycrystalline thin films of mixed-valency metal oxides", Mater. Sci. Eng., B 18, 201 (references are therin).

[11] Campet, G., Portier, J., Morel, B., Ferry, D., Chabagno, J. M., Bentomane, L. and Bourrel, M. (1992). "Hithly Reversible Electrochemical Insertion of Lithium Accompanied with a Marked Color Change, Occuring in Microcrystalline Lithium Nickel Oxide films", Active and Passive Electronic Compounds, 14, 219.

[12] Graetzel, M., Bonhote, P. and Dias, A. P. (1994). "Nouveaux Sels Liquides Hydrophobes". France Patent $N^{\circ}$ 94, 15704.

[13] Choy, J.-H., Park, N.-G., Kim, Y.-I. and Yoon, J.-B. (1996). "Hydrophobic Lithium Ion Conducting Electrolyte". Korean Patent, accepted.

[14] Camino, D. (1996). "Etude de 1'Insertion d'Ions Lithium dans les Couches Minces de $\mathrm{TiO}_{2}$ et $\mathrm{TiO}_{2}-\mathrm{CeO}_{2}$ ", Ph. D. thesis, Université de Bordeaux I, France.

[15] Camino, D., Deroo, D., Salardenne, J. and Treuil, N. (1995). " $\left(\mathrm{CeO}_{2}\right)_{x}-\left(\mathrm{TiO}_{2}\right)_{1-x}$ : Counter Electrode Materials for Lithium Electrochromic Devices”, Solar Energy Mat. and Solar Cells, 39, 2349 (references are therin). 

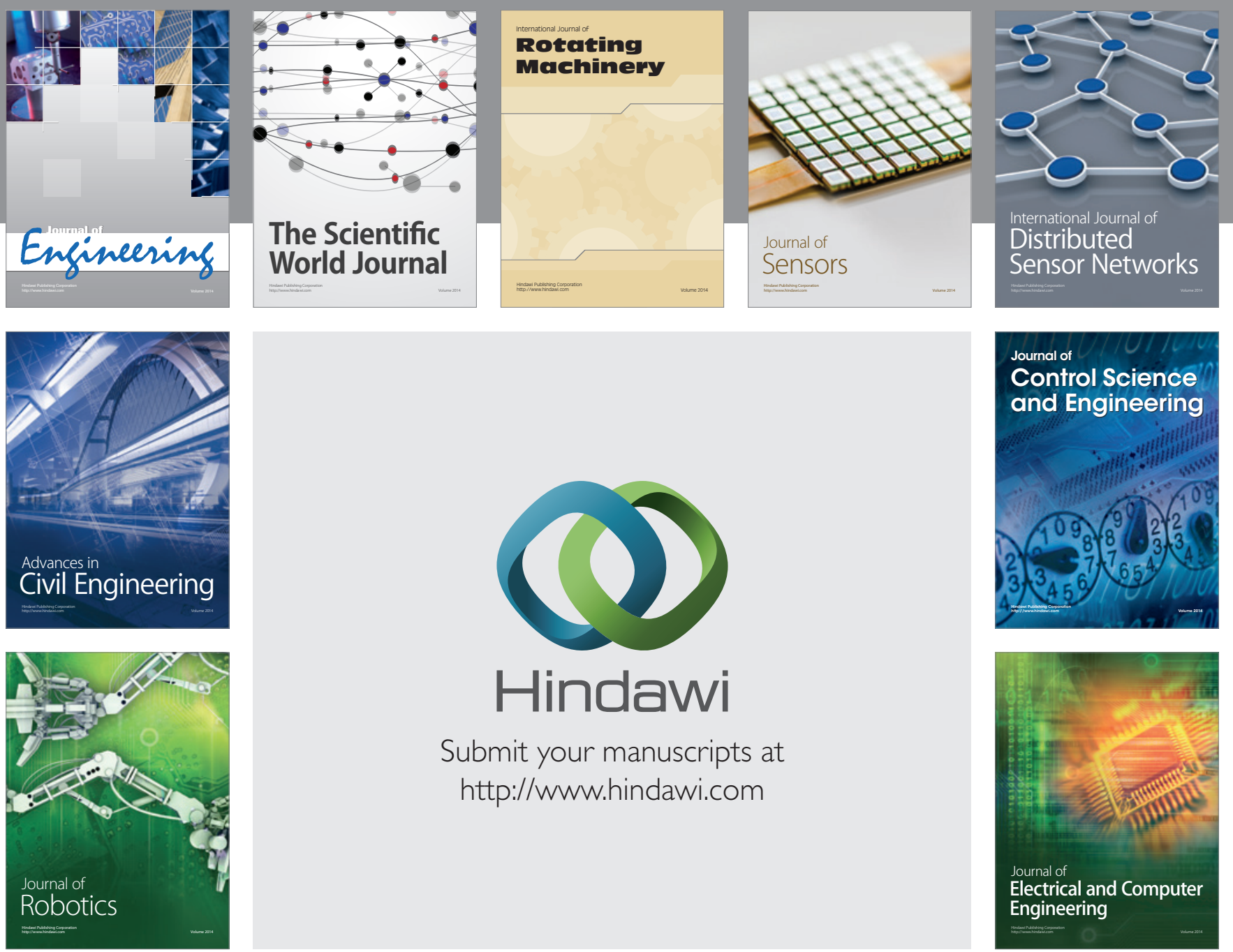

Submit your manuscripts at

http://www.hindawi.com
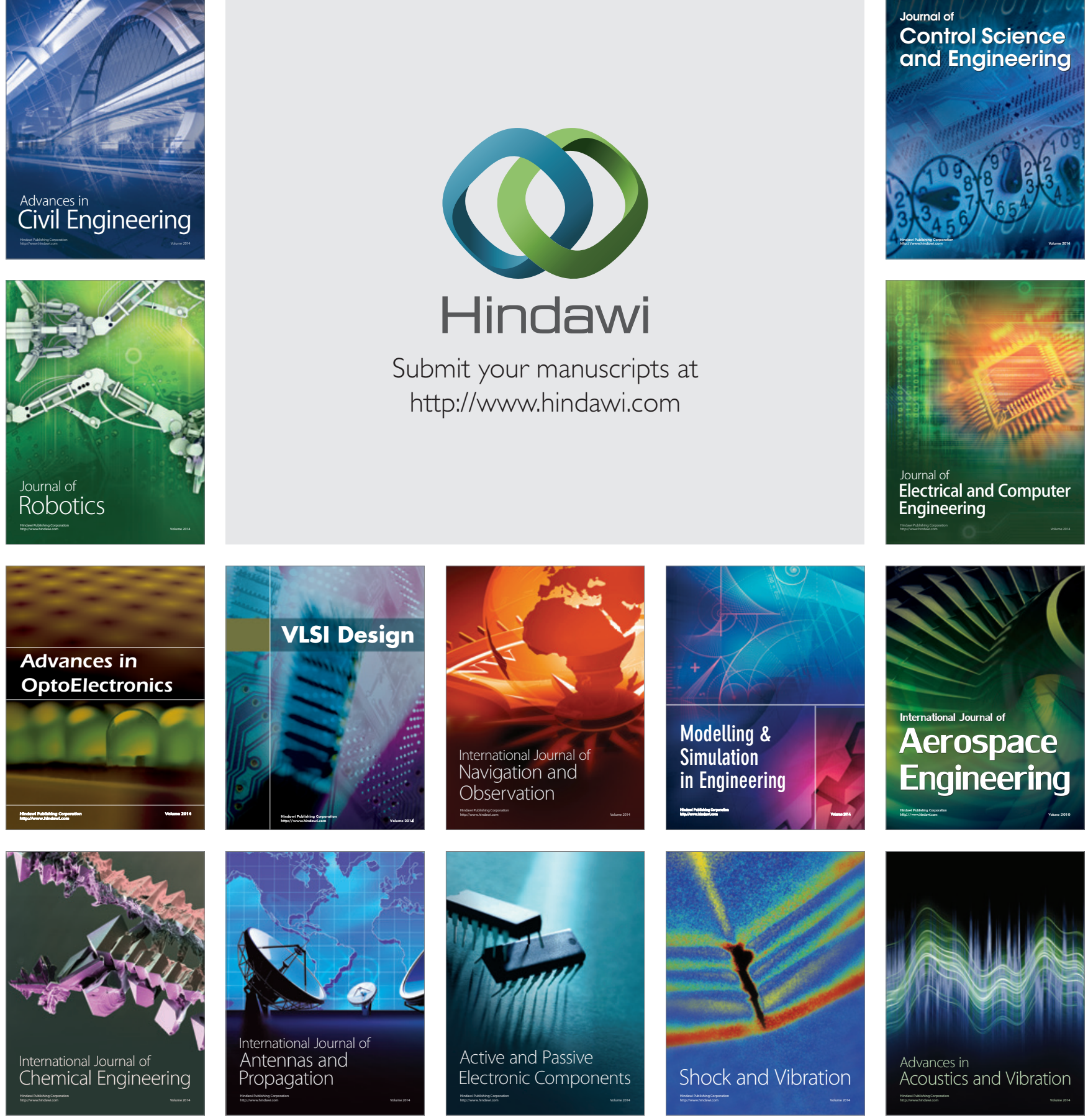